\title{
A Novel Approach to Reinstating Tolerance in Experimental Autoimmune Myasthenia Gravis Using a Targeted Fusion Protein, mCTA1-T146
}

\author{
Alessandra Consonni', Sapna Sharma², Karin Schön², Cristina Lebrero-Fernández², \\ Elena Rinaldi', Nils Yngve Lycke ${ }^{2 *+}$ and Fulvio Baggi't \\ ${ }^{1}$ Neurology IV, Fondazione I.R.C.C.S. Istituto Neurologico Carlo Besta, Milan, Italy, ${ }^{2}$ Department of Microbiology and \\ Immunology, Institute of Biomedicine, University of Gothenburg, Gothenburg, Sweden
}

OPEN ACCESS

Edited by:

Bert A. 't Hart,

Biomedical Primate Research

Centre, Netherlands

Reviewed by:

Mario Losen,

Maastricht University,

Netherlands

Todd Eagar,

Houston Methodist Research Institute, United States

Cris S. Constantinescu,

University of Nottingham,

United Kingdom

${ }^{*}$ Correspondence:

Nils Yngve Lycke

nils.lycke@microbio.gu.se

these investigators contributed equally as senior authors.

Specialty section: This article was submitted to

Multiple Sclerosis and

Neuroimmunology,

a section of the journal

Frontiers in Immunology

Received: 19 June 2017

Accepted: 28 August 2017 Published: 13 September 2017

Citation:

Consonni A, Sharma S, Schön K, Lebrero-Fernández C, Rinaldi $E$, Lycke NY and Baggi F (2017) A Novel Approach to Reinstating Tolerance in

Experimental Autoimmune

Myasthenia Gravis Using a Targeted Fusion Protein, MCTA1-T146.

Front. Immunol. 8:1133. doi: 10.3389/fimmu.2017.01133
Reinstating tissue-specific tolerance has attracted much attention as a means to treat autoimmune diseases. However, despite promising results in rodent models of autoimmune diseases, no established tolerogenic therapy is clinically available yet. In the experimental autoimmune myasthenia gravis (EAMG) model several protocols have been reported that induce tolerance against the prime disease-associated antigen, the acetylcholine receptor (AChR) at the neuromuscular junction. Using the whole AChR, the extracellular part or peptides derived from the receptor, investigators have reported variable success with their treatments, though, usually relatively large amounts of antigen has been required. Hence, there is a need for better formulations and strategies to improve on the efficacy of the tolerance-inducing therapies. Here, we report on a novel targeted fusion protein carrying the immunodominant peptide from AChR, mCTA1-T146, which given intranasally in repeated microgram doses strongly suppressed induction as well as ongoing EAMG disease in mice. The results corroborate our previous findings, using the same fusion protein approach, in the collagen-induced arthritis model showing dramatic suppressive effects on Th1 and Th17 autoaggressive CD4 T cells and upregulated regulatory T cell activities with enhanced IL10 production. A suppressive gene signature with upregulated expression of mRNA for TGF $\beta$, IL10, IL27, and Foxp3 was clearly detectable in lymph node and spleen following intranasal treatment with mCTA1-T146. Amelioration of EAMG disease was accompanied by reduced loss of muscle AChR and lower levels of anti-AChR serum antibodies. We believe this targeted highly effective fusion protein MCTA1-T146 is a promising candidate for clinical evaluation in myasthenia gravis patients.

Keywords: tolerance, adjuvant, vaccination, dendritic cells, myasthenia gravis, autoimmune disease, cholera toxin

\section{INTRODUCTION}

Myasthenia Gravis (MG) is an autoimmune disease characterized by muscle weakness and fatigability, which, in most cases, is the result of autoantibody production against the acetylcholine receptor $(\mathrm{AChR})$ at the neuromuscular junction $(1,2)$. Although the disease is strongly associated with autoantibody production, the AChR-specific $\mathrm{CD} 4^{+} \mathrm{T}$ cells have a central regulatory role 
and, indeed, also patients lacking anti-AChR antibodies host peripheral blood $\mathrm{CD}^{+} \mathrm{T}$ cells that react to AChR-peptides $(3,4)$. Importantly, MG patients have reduced levels of regulatory T cells (Tregs) (5-8) and restoring the levels of Tregs in the experimental autoimmune myasthenia gravis (EAMG) model suppressed disease (9). Hence, reinstating a functional Treg population could be a curative therapeutic intervention in MG (10). Both Th1 and Th17 cells have been implicated in driving the autoimmune attack, but the precise contribution of the respective subset remains unclear (11-13). Evidence in support of an involvement of Th17 cells in the EAMG model has been documented in several recent studies, while earlier studies, for example, in $\mathrm{Tbet}^{-/-}$mice demonstrated reduced susceptibility to EAMG as a consequence of fewer autoreactive Th1 cells (14).

Current treatments for autoimmune diseases are not curative, but rather are directed against the immunopathology and symptoms $(15,16)$. Also in MG, the first line of treatment is symptomatic, counteracting the muscle fatigability using acetylcholinesterase inhibitors, while some patients need additional medication with steroids or other forms of immunosuppressants, such as azathioprine, mycophenolate, or methotrexate. In the more severe cases, monoclonal antibodies such as anti-CD20 (rituximab) or, for short-term benefit, intravenous immunoglobulin or even plasmapheresis/immunoadsorption are being used (17). The medication has to be taken life-long with an increased risk of acquiring infectious diseases or even cancer, secondarily to severe side effects (15). Therefore, there is growing interest in developing novel therapies able to suppress autoaggressive $\mathrm{T}$ cells and reinstate tolerance in the immune system (18).

One such approach is to use adoptive cell transfer of ex vivo expanded autologous CD4 ${ }^{+}$Treg cells to inhibit disease development as has been successfully demonstrated in the EAMG model (9). Other investigators have focused on identifying immunodominant epitopes in the AChR to raise Tregs by immunization and in this way protect against disease development (19). Thus, restoring a functional Treg population by immunization with immunodominant epitopes from the AChR appears to be an attractive therapeutic approach for curbing MG disease. A major challenge, though, has been to translate the very promising findings in the rodent EAMG models into effective immunization protocols for treatment of MG patients $(20,21)$. This could partly be explained by the lack of effective formulations for toleranceinduction in humans as both disease-relevant peptides and proteins have already been identified but clinical testing still awaits to be done $(18,22-25)$. Hence, we need better ways of formulating our candidate epitopes to secure a strong induction of tolerance also in the clinic.

We have developed CTA1R9K-X-DD, which is a targeted immunomodulating fusion protein that can carry different disease-relevant peptides and which is an effective tolerogenic vector for the suppression of autoaggressive CD4 T cells (26). The fusion protein is an inactivated mutant of the CTA1 subunit of cholera toxin, which in its native form exerts strong ADP-ribosylating effects (26). The DD is a dimer of a fragment of Staphylococcus aureus proteinA, which targets classical dendritic cells (27). Using the collagen-induced arthritis (CIA) mouse model, we could demonstrate that a collagen peptide (aa 259-274) inserted into the fusion protein, CTA1R7K$\mathrm{COL}_{259-274-\mathrm{DD}}$, and given as an intranasal (i.n.) therapy or orally in the form of edible plants effectively protected against CIA $(26,27)$. Following treatment with CTA1R7K-COL $259-274-\mathrm{DD}$, we found suppression of specific antibody levels in serum, reduced effector Th1 and Th17 CD4 T cell responses to peptide concomitant with an increased production of IL-10, while IL-6 and MMP3 levels were strongly reduced $(26,27)$. Although we observed increased numbers of circulating Foxp $3^{+}$Tregs, the increased IL-10 production emanated from regulatory Foxp $3^{-}$ CD4 T cells, i.e., Tr1-like cells (28).

In the present study, we have extended our work to the EAMG model. We hypothesized that the mechanism of action in the EAMG model could be the induction of $\operatorname{Tr} 1$ cells and the subsequent reinstatement of tolerance to the AChR. Therefore, a disease-relevant peptide, the 146-162 amino acid peptide from AChR, was expressed as a fusion protein, CTA1R9K$\mathrm{AChR}_{146-162}$-DD (hereinafter referred as mCTA1-T146). This fusion protein, thus, carried a dominant epitope from the AChR for treatment of EAMG in C57Bl/6 mice $(29,30)$. We report here the successful use of this fusion protein in both acute and chronic stages of EAMG disease. Treated mice developed significantly less symptoms and exhibited less tissue destruction and lower serum anti-AChR antibody titers. Lymph node cells in treated mice demonstrated upregulated gene expression of TGF $\beta$, IL10, IL27, and Foxp3, a suppressive gene signature, concomitant with suppressed Th1 and Th17 CD4 ${ }^{+} \mathrm{T}$ cell development $(31,32)$.

\section{RESULTS}

\section{Intranasal Treatment Suppresses CD4 ${ }^{+}$ T Cell Priming in the EAMG Model}

Previous studies in the CIA model suggested that immune tolerance could also be achieved in other models of autoimmune diseases, provided disease-relevant peptides were incorporated in the CTA1R9K-X-DD fusion protein (26). Therefore, we designed, expressed, and purified a fusion protein, mCTA1-T146, which carried a dominant epitope corresponding to the aa 146-162 sequence from the alpha subunit of the torpedo AChR (30) for treatment of disease in the EAMG mouse model $(21,33)$. In order to study the effect of the fusion protein, TAChR-primed mice were given the fusion protein mCTA1-T146 or PBS i.n. on days 2, 4, 10, and 12 after the s.c. immunization. Mice were sacrificed on day 18 and the immune response to TAChR was evaluated in single cell suspensions from the spleen and draining (inguinal and popliteal) lymph nodes (Figure 1A). We observed a striking suppression of the $\mathrm{CD}^{+} \mathrm{T}$ cell recall response to both TAChR and T146-162 peptide in the draining lymph nodes and spleen in mice treated with the mCTA1-T146 fusion protein, while PBS-treated mice showed robust responses (Figures $\mathbf{1 B}, \mathbf{C}$ ). In particular, $\mathrm{CD}^{+} \mathrm{T}$ cell proliferation in the draining lymph nodes and spleen was reduced by $70-80 \%$ (Figures $\mathbf{1 B}, \mathbf{C}$ ). The lower recall responses were also reflected in poor cytokine production, with dramatically reduced IFN $\gamma$, IL17, and IL10 levels in culture supernatants from mCTA1T146 treated as compared to PBS-treated mice (Figures 1D-F). 


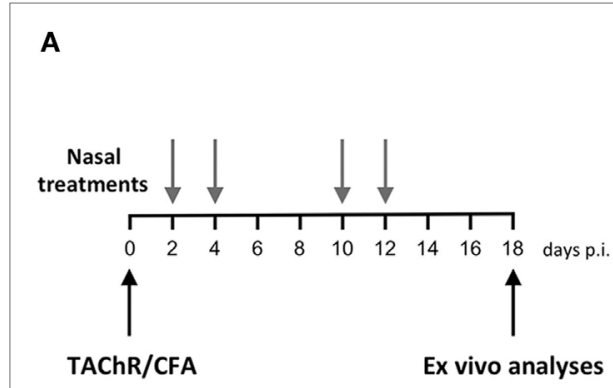

D

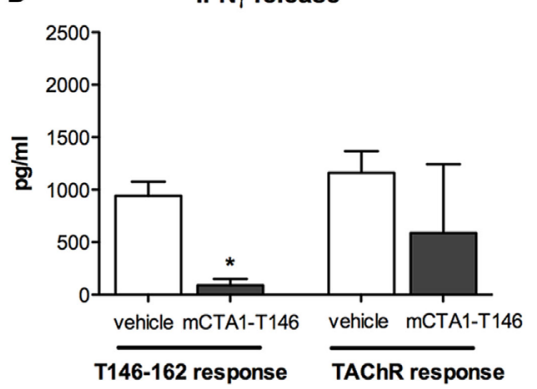

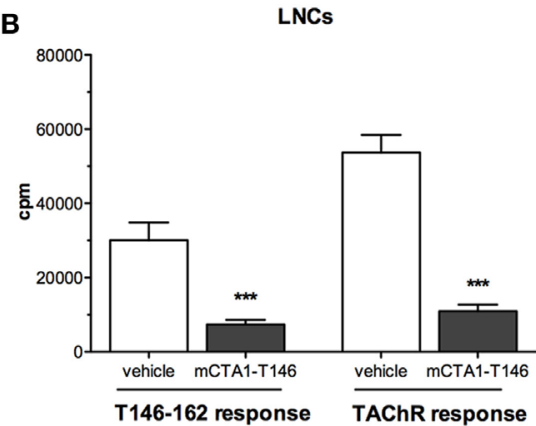

C

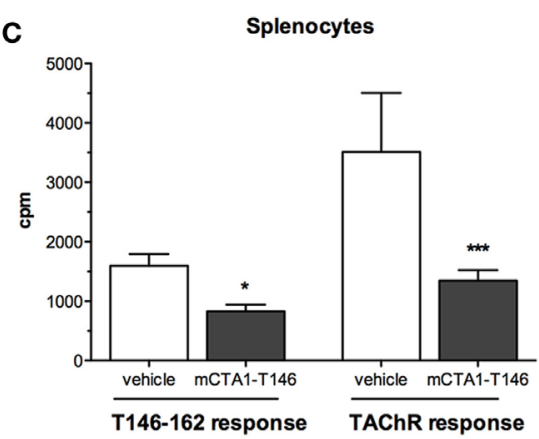

E

IL17 release

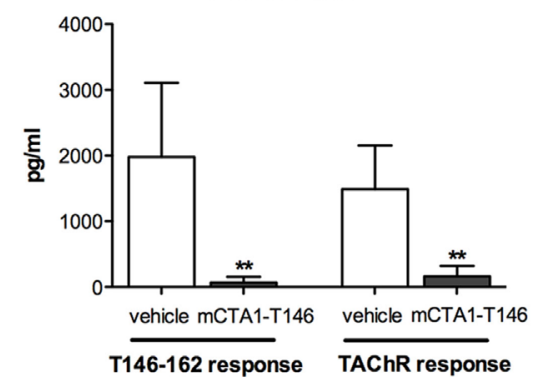

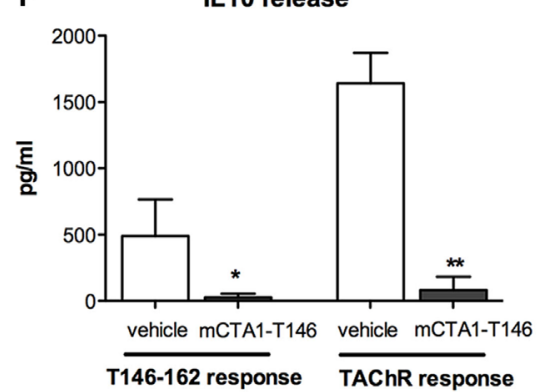

IL10 release

FIGURE 1 | Intranasal mCTA1-T146 treatment strongly suppresses CD4+ T cell priming. (A) Experimental design: a single s.c. injection of TAChR at the base of the tail followed by four nasal treatments with mutant CTA1R9K-AChR ${ }_{146}-\mathrm{DD}$ (mCTA1-T146) (5 $\left.\mathrm{mg} / \mathrm{dose}\right)$ or PBS (vehicle). On day 18, popliteal and inguinal LNCs (B) and splenocytes (C) were analyzed for proliferation to recall antigen TAChR protein $(0.25 \mu \mathrm{g} / \mathrm{ml})$ or T146-162 peptide $(10 \mu \mathrm{g} / \mathrm{ml})$. After $72 \mathrm{~h}$, supernatants from cultured LNCs were evaluated for IFN $\gamma$ (D), IL17 (E), and IL10 (F) cytokine release using multiparametric assay (Luminex). Representative experiment of two; $n=5$ mice per group. Data represent means of mice analyzed individually with isolated cells in triplicate cultures and given as mean $\mathrm{cpm} \pm \mathrm{SEM}(\mathbf{B}, \mathbf{C})$ or pg/ml $\pm \mathrm{SD}$ (D-F). Significance was calculated with Mann-Whitney test. $p$-Values are represented by ${ }^{\star} p<0.05,{ }^{\star \star} p<0.01$, and ${ }^{\star \star \star} p<0.001$.

\section{The mCTA1-T146 Fusion Protein Protects against EAMG Disease}

Next, we extended the analysis to include long-term effects of the mCTA1-T146 fusion protein on the development of EAMG disease. We evaluated different treatment protocols as shown in Figure 2A, and mice were carefully monitored for disease development. Irrespective of whether the fusion protein was administered at an early phase of disease-induction (Figure 2B) or later, during the chronic phase of the disease (Figures 2C-E), we achieved strong suppressive effects of i.n. mCTA1-T146 fusion protein on disease manifestations compared to PBS or treatments with irrelevant fusion proteins. We observed significantly reduced EAMG clinical scores (Figures 2B-E). While disease scores at the end of the experiments were near 2 or above in PBS-treated EAMG mice, disease severity in mCTA1-T146 treated mice was always near or below 1 . We also evaluated the clinical efficacy of 10 i.n. doses (therapeutic protocols B and $\mathrm{C}$, Figure 2A), compared to the 15 doses used in the first experiments (preventive protocol A and therapeutic protocol A, Figure 2A), but we found no statistical difference between the two protocols, arguing that both the number of treatments and the total amount of fusion protein could be reduced and still a strong suppressive effect was achieved (Figures 2D-E). The effect of the treatment was also detectable as significantly less weight loss compared to untreated (PBS) EAMG diseased mice using the therapeutic protocol (Figure 2F). Mice treated with a fusion protein without the AChR-peptide (mCTA1-empty, Figure 2B), or with a fusion protein containing an irrelevant control peptide (mCTA1-OVA, Figure 2C), or with equimolar doses of peptide alone (Figure 2D) failed to show any significant effects on disease manifestations.

\section{Treatment Effects Are Reflected in Suppressed AChR-Specific Antibody Levels and Preserved Muscle AChR Content}

Experimental autoimmune myasthenia gravis disease is associated with increased anti-AChR antibody levels in serum and loss of muscular AChR content. We found the accompanying increased serum anti-AChR antibody levels in EAMG disease less prominent in mCTA1-T146 treated as opposed to PBS-treated control mice. In fact, a significantly lower anti-AChR serum titer was found in mCTA1-T146-treated as compared to both PBS- or control fusion protein (mCTA1-empty or mCTA1-OVA)-treated mice (Figures $3 \mathrm{~A}, \mathrm{C}$ ). We also evaluated $\mathrm{AChR}$ content in muscles from treated and untreated EAMG mice: higher levels of muscle AChR content were found in mCTA1-T146-treated EAMG mice compared to PBS- or control fusion protein-treated mice (mCTA1-empty or mCTA1-OVA) (Figures 3B,D). Moreover, the muscular AChR content in mCTA1-T146-treated mice was not significantly lower than that recovered in muscle from 


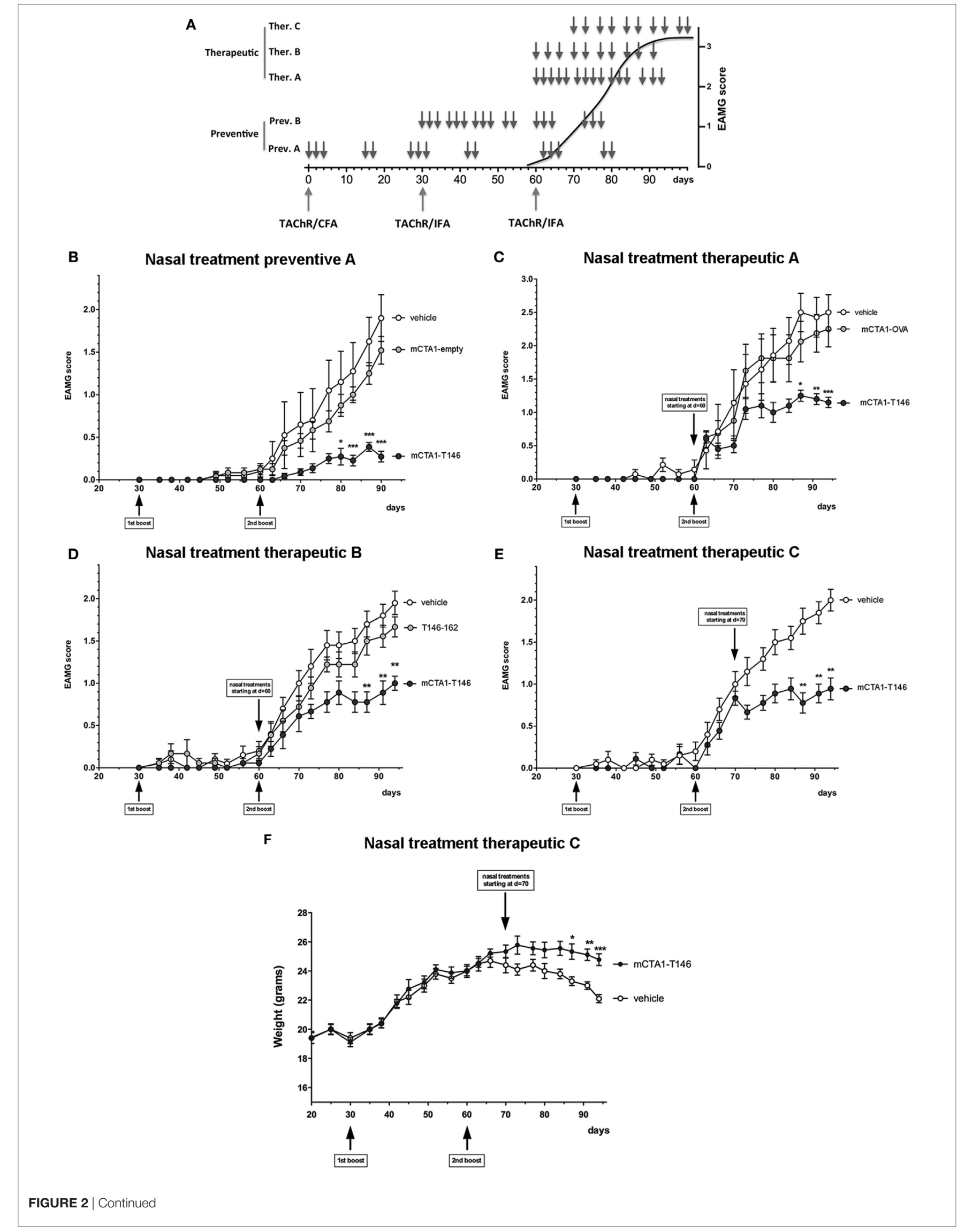


FIGURE 2 | Continued

Intranasal treatment with mCTA1-T146 protects against experimental autoimmune myasthenia gravis (EAMG) disease. (A) Treatment protocols evaluated in the mouse EAMG model. Animals were i.n. treated with CTA1R9K-AChR 146 -DD (mCTA1-T146) fusion protein or control treatments with empty CTA1R9K-DD vector (mCTA1-empty), CTA1R9K-OVAp323-DD (mCTA1-OVA), all at $5 \mu \mathrm{g} / \mathrm{dose}$, or peptide alone T146-162 at $0.25 \mu \mathrm{g} /$ dose, according to preventive (Prev.) or therapeutic (Ther.) protocols. Clinical EAMG score in the indicated groups are given for: (B) preventive protocol $\mathrm{A}(15 \mathrm{doses}$, from $d=0)$, (C) therapeutic protocol $\mathbf{A}$ after second TAChR boost (15 doses, from $d=60$ ), (D) therapeutic protocol B after second TAChR boost (10 doses, from $d=60$ ) and (E) therapeutic protocol C with clinical scores and (F) showing weight curves for $(\mathbf{E})$ in mice with treatments starting on $d=70$ and 10 i.n. doses. $N=10$ mice/group; data are expressed as means \pm SEM and significance was calculated with 2-way-ANOVA analysis plus Bonferroni post hoc comparisons. $p$-Values are represented by ${ }^{*} p<0.05$, ${ }^{* *} p<0.01$, and ${ }^{* * *} p<0.001$.

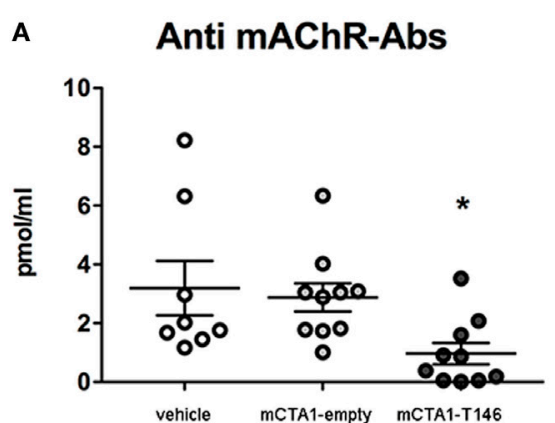

c Anti mAChR-Abs

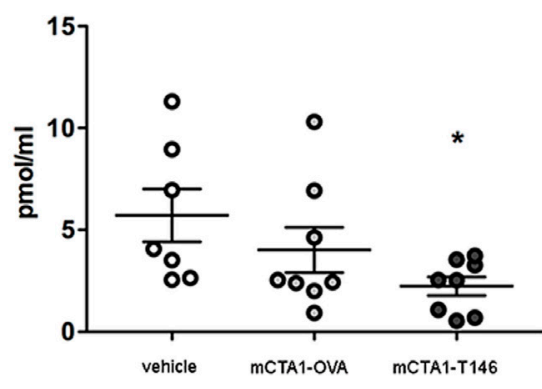

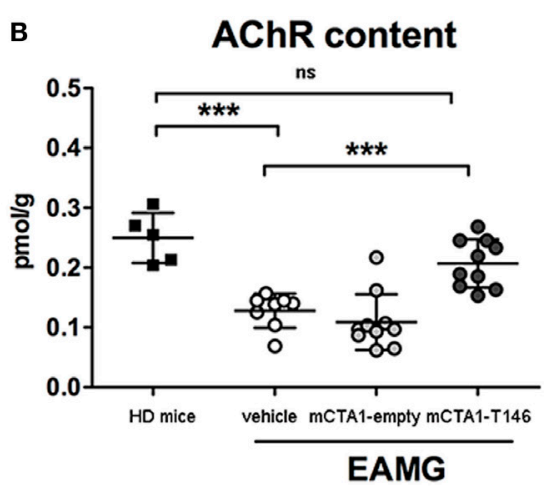

D AChR content

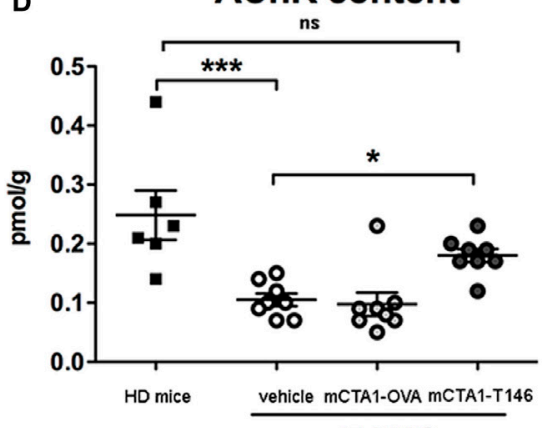

EAMG

FIGURE 3 | Tolerogenic treatment with mCTA1-T146 protects against loss of muscular acetylcholine receptor (AChR) and impairs anti-AChR-specific serum antibody responses. Anti-AChR serum antibody levels (pmol/ml) in individual mice from Prev. $\mathbf{A}(\mathbf{A})$ or Ther. A (C) protocols used for protection against experimental

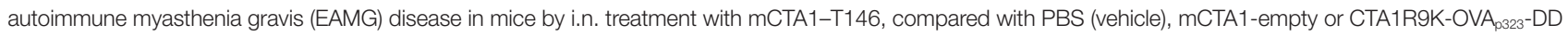
(mCTA1-OVA). The muscle content of AChR for individual mice was determined using a radioimmunoassay and total muscle AChR content (pmol/g of tissue) is given in healthy donor mice (HD mice) compared to that detected in mice undergoing i.n. tolerizing treatment according to Prev. A (B) or Ther. A (D) protocols - values are given for individual mice in pmol/ml and means \pm SEM of serum antibody levels or AChR muscle content for individual mice in pmol/g and means \pm SEM. Significance was calculated with one-way ANOVA analysis plus Dunnet post hoc comparisons. $p$-Values are represented by ns, not significant; ${ }^{\star} p<0.05$; ${ }^{\star \star \star} p<0.001$.

healthy mice. This was apparent in both early (Figure 3B) and late (Figure 3D) treatment protocols. Thus, the i.n. treatment with mCTA1-T146 fusion protein prevented from loss of muscle $\mathrm{AChR}$ content, and this was associated with a significantly reduced level of anti-AChR serum antibodies.

\section{Suppression of EAMG Disease Is Associated with Lower IFN $\gamma$ and IL17 Production and Upregulated Expression of TGF $\beta$, IL10, IL27, and FOXP3 Genes}

We evaluated the CD4 $\mathrm{T}$ cell responses to recall antigen in the draining lymph nodes derived from mCTA1-T146-treated mice.
Results from three different treatment protocols were compared (Prev. A, Ther. B and C). We found significantly impaired $\mathrm{CD}^{+} \mathrm{T}$ cell proliferation in draining lymph nodes to both the TAChR and T146-162 peptide (Figures 4A,B, respectively). The cytokine responses induced exhibited substantially reduced IFN $\gamma$ and IL17 production, while IL10 levels were increased in mCTA1-T146 culture supernatants from treated mice as compared to PBS-treated mice (Ther. A Figures 2 and 4B). Furthermore, the mRNA expression levels of some critical genes were assessed in draining lymph nodes and spleen and compared to those found in PBS-treated animals. Whereas PBS-treated mice exhibited strongly enhanced expression of mRNAs encoding IFN $\gamma$ and IL17 in lymph node cells, these effector cytokine 


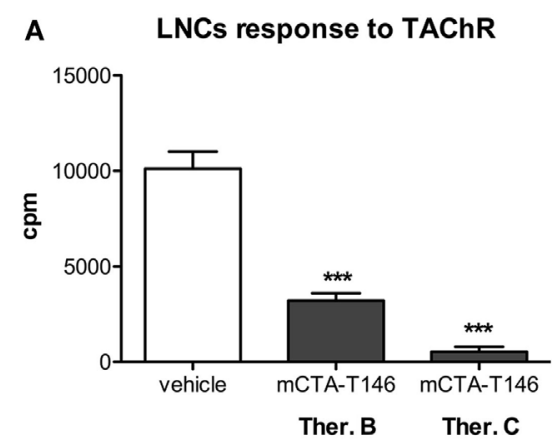

B

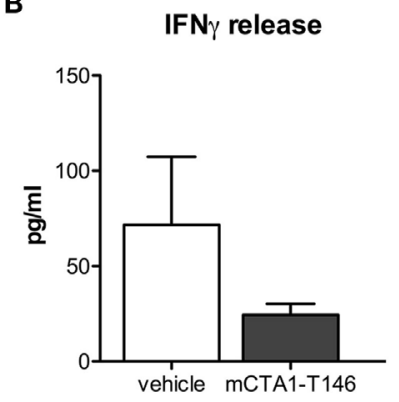

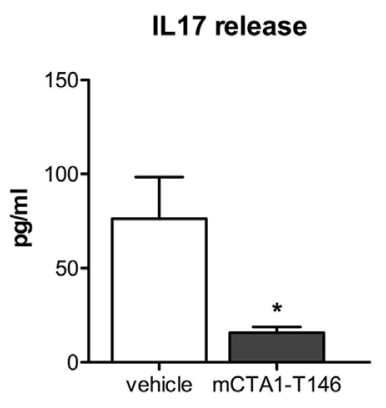

LNCs response to T146-162

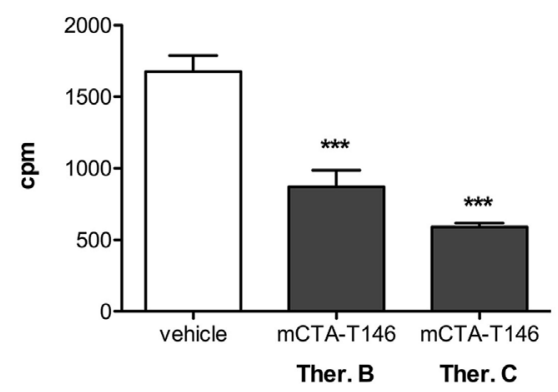

IL10 release

Prev. A

FIGURE 4 | Tolerization with mCTA1-T146 effectively suppresses autoaggressive lymph node T cell functions and promotes regulatory T cells. (A) LNCs responses to recall antigen TAChR $(0.25 \mu \mathrm{g} / \mathrm{ml})$ or $\mathrm{T} 146-162$ peptide $(10 \mu \mathrm{g} / \mathrm{ml})$ were assessed. Cells were isolated from experimental autoimmune myasthenia gravis mice following i.n. treatment with PBS (vehicle) or the tolerogen CTA1R9K-AChR ${ }_{146}$-DD (mCTA1-T146) as indicated; animals received the therapeutic protocol B (Ther. B), therapeutic protocol C (Ther. C), or preventive protocol A (Prev.A). LNCs proliferation is given as mean cpm values \pm SEM. (B) Cytokine production in LNCs supernatants; data are expressed as mean $\mathrm{pg} / \mathrm{ml} \pm \mathrm{SD}$. Representative experiments of four, $n=10$ mice per group; significance was calculated with Mann-Whitney test. $p$-Values are represented by ${ }^{\star} p<0.05 ;{ }^{* \star *} p<0.001$

mRNAs were dramatically reduced in mCTA1-T146-treated mice (Figure 5A). By contrast, mCTA1-T146-treated mice exhibited enhanced TGF $\beta$, IL10, IL27, and Foxp3 mRNA levels compared to those found in PBS-treated mice (Figure 5A). This pattern of gene expression was also observed in splenocytes from treated as opposed to control mice (Figure 5B). Hence, genes encoding TGF $\beta$, IL10, IL27, and FoxP3 cytokines, associated with immune suppression of Th1 and Th17 effector CD4 ${ }^{+} \mathrm{T}$ cell development, were significantly more expressed in lymph nodes and spleens in mCTA1-T146-treated as opposed to PBS-treated mice. Taken together, our data indicated a strong tolerogenic effect of mCTA1-T146, effectively suppressing autoaggressive effector $\mathrm{CD}^{+} \mathrm{T}$ cell functions. Accordingly, it appeared that mCTA1-T146 treatment in EAMG mice promoted immune tolerance by reinstating immunoregulatory $\mathrm{CD} 4^{+} \mathrm{T}$ cells. Both Tregs and $\operatorname{Tr} 1 \mathrm{CD} 4^{+} \mathrm{T}$ cells could be involved in this tolerance (34). Interestingly, the IL27 pathway, known to promote $\operatorname{Tr} 1$ cell differentiation, appears to be involved, which corroborates earlier findings with our tolerogen in the CIA model (Figures 5A,B).

\section{DISCUSSION}

The present study identifies a novel approach to treating MG disease by reinstating tolerance against the AChR using the targeted fusion protein mCTA1-T146. We provide compelling evidence in the mouse EAMG model that i.n. treatment with mCTA1T146 is effective at an early as well as at a later chronic stage of the disease with significantly less tissue destruction, i.e., higher muscle AChR content, and lower serum anti-AChR antibody titers than in untreated mice. This has important implications for the feasibility of developing a clinical treatment for MG patients. Moreover, the effect on lowering the clinical score was associated with an immune suppressive gene signature involving upregulation of genes encoding for IL10, IL27, TGF $\beta$, and FoxP3 in the draining lymph nodes and spleen. These genes have been found strongly linked to a protective effect on autoimmune reactions (35). Most importantly the production of AChR-specific IFN $\gamma$ and IL17, key cytokines representing Th1 and Th17 functions, respectively, were significantly suppressed in mCTA1-T146treated mice. In this way, the present findings corroborate and extend our previous documentation of a Tr1-mediated suppressive effect of the fusion protein on autoaggressive $\mathrm{CD}^{+} \mathrm{T}$ cells in the CIA model (26).

The pioneering experiments showing that mucosal administration of native TAChR in rats induces tolerance dates back to the early 1990s when nasal or oral delivery was shown to suppress EAMG disease $(29,36,37)$. Since then, several studies have been published that convincingly demonstrate that mucosal delivery of AChR or its recombinant extracellular $\alpha 1$ domain effectively suppresses induction of EAMG in both the rat and mouse EAMG 

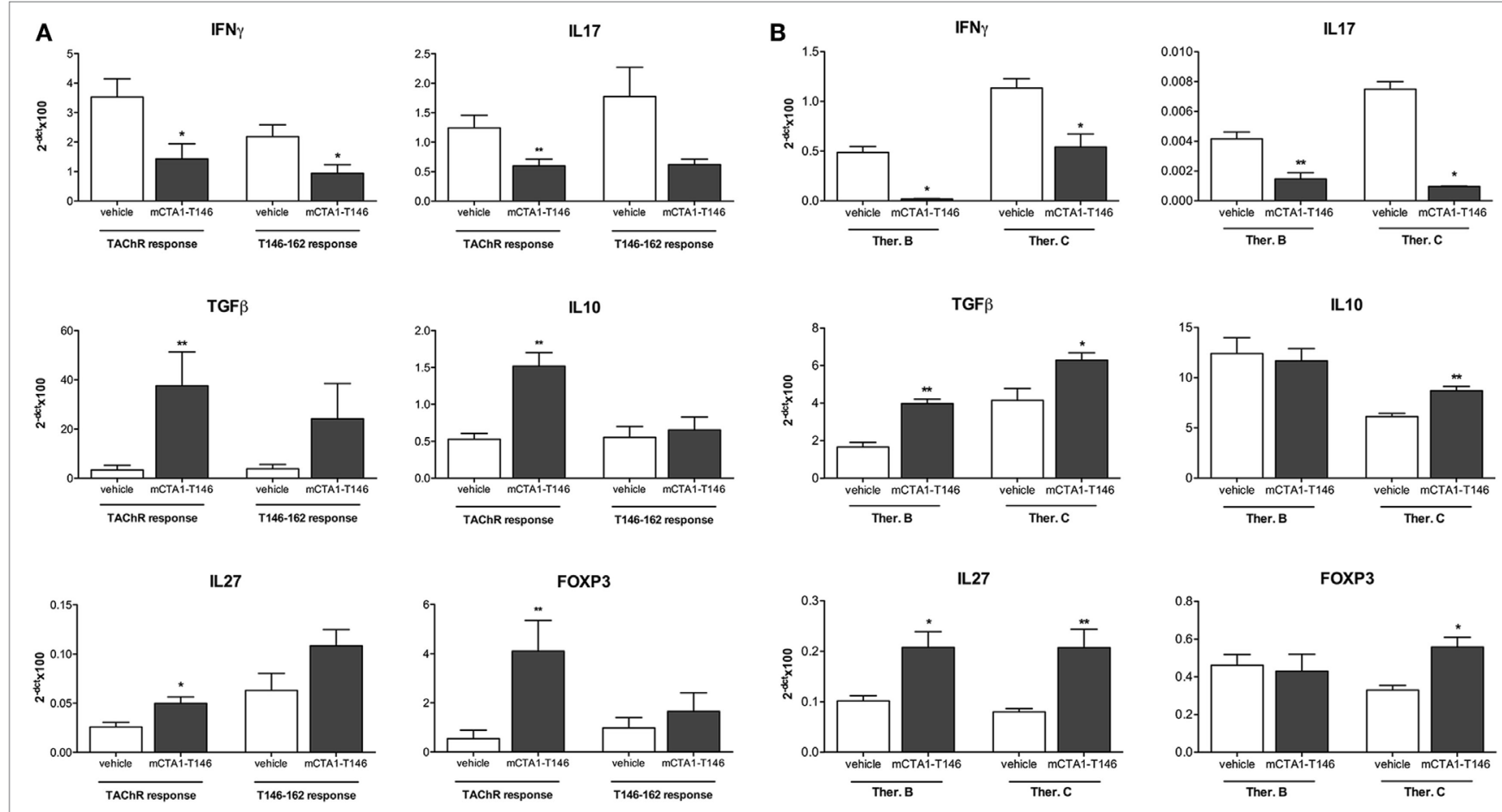

FIGURE 5 | Suppression of genes encoding effector cytokines while upregulating genes encoding tolerance-induction in CD4 T cells after i.n. treatment with the mCTA1-T146 in experimental autoimmune myasthenia gravis (EAMG) mice. mRNA expression of genes encoding the pro-inflammatory cytokines IFN $\gamma$ and IL17 or regulatory genes encoding TGF $\beta$, IL10, IL27, and Foxp3 were assessed in cultured LNCs (A) or spleen (B) of tolerogen- (mCTA1-T146) or PBS (vehicle)-treated EAMG mice, as described in Figure 4. Cells were in vitro stimulation for $72 \mathrm{~h}$ with TAChR $(0.25 \mu \mathrm{g} / \mathrm{ml})$ or T146-162 peptide ( $25 \mu \mathrm{g} / \mathrm{ml})$, and $\mathrm{mRNA}$ analyzed by qRT-PCR. EAMG mice were treated i.n. with the tolerogen CTA1R9K-AChR 146 -DD (mCTA1-T146) or PBS (vehicle) according to protocol therapeutic B (Ther. B) and C (Ther. C). mRNA values were normalized to the GAPDH housekeeping gene and expressed as mean $2^{-\Delta c t} \times 100 \pm$ SEM. Representative experiment of two, $n=10$ mice per group; significance was calculated with Mann-Whitney test. $p$-Values are represented by ${ }^{*} p<0.05$; ${ }^{\star \star} p<0.01$.

models (38). Notably, it was observed that in ongoing EAMG it was significantly more difficult to suppress the disease and it usually, but not always, required much larger doses of antigen $(19,39)$. Also peptides have been used for tolerization and it has been well documented that most often large doses (50-100 $\mu \mathrm{g}$ or more) are required for suppressing induction of EAMG disease $(29,40,41)$. It is in this context, we believe our targeted fusion protein, mCTA1-T146, adds to the therapeutic arsenal of AChR-specific tolerance-inducing strategies.

We found that repeated nasal treatments with a low dose of mCTA1-T146 effectively ameliorated EAMG disease resulting in less reduction in muscle AChR content and lower levels of serum anti-AChR antibodies. Because the peptide T146-162 is incorporated into the fusion protein, it has to be taken up and be processed by antigen-presenting cells (APC) to induce tolerance (27). This is contrary to the peptide approach where uptake by APC and processing are not involved and, indeed, the term apitope has been coined to identify an antigen-processing independent epitope (42-44). Therefore, the mechanisms of action can potentially be different between a peptide approach and that of the fusion protein. In particular, lower molar doses would be expected to be required for a tolerance-inducing effect by the fusion protein, which is also supported in our study when comparing the fusion protein with an equimolar dose of peptide that failed to induce tolerance. However, in the experimental autoimmune encephalomyelitis (EAE) model, apitope-induced tolerance was also mediated by IL-10 producing Foxp3-negative Tr1 cells, similar to what we think our mCTA1-T146 fusion protein does in the EAMG model (45). Nevertheless, we believe the fusion protein approach may have certain merits as it is possible to attach targeting elements to the peptides. In the mCTA1T146 fusion protein, we have explored the DD-moiety for its DC targeting ability. Given i.n. the migratory DCs of the CD103 ${ }^{+}$ phenotype are the primary targets for inducing tolerance (46, 47). Indeed, in preliminary experiments we could also show that our fusion protein accumulated in $\mathrm{CD}_{103^{+}}$migratory DC following i.n. administration (C. Hansson, Univ. of Gothenburg, Sweden, personal communication).

The critical disease-preventing element in the fusion protein is the AChR-specific peptide T146-162. Hence, the immune system in general is, therefore, unperturbed and functional for protection against, e.g., pathogens. Moreover while the fusion protein is carrying the T146-162 peptide, rather than the whole extracellular $\alpha 1$ of $\mathrm{AChR}$, i.e., aa 1-210, the peptide approach largely avoids an immunogenic and potentially pathological reactivity to $B$ cell epitopes in the protein (3). Hence, this also limits the risk of disease exacerbation following treatment should a enhancing rather than a suppressive anti-AChR-specific antibody response be elicited, including potential epitopes due to renaturation of conformation-dependent epitopes $(3,39,48$, 
49). This is also the reason why investigators have avoided the main immunogenic region (i.e., aa 66-76) loop when developing $\alpha 1$ region based tolerogenic treatments and why cytoplasmatic domains rather than the extracellular $\alpha 1$ region of the AChR are being used for tolerance induction $(3,50)$. However, it appears that rather large doses are required for tolerance induction using this approach, at least in the rat EAMG model (48).

According to the guidelines for the mouse EAMG model, the quality of the TAChR preparation is important to get a high take of disease (21). In this study, we achieved 95\% incidence of disease. Although, our preparation could have contained low levels of contaminating other synaptic proteins (see Materials and Methods), we specifically tolerized against the T146 peptide of the AChR, and, hence, we suppressed CD4 T cell reactivity against the AChR with positive clinical manifestations. However, additional incorporated peptides, representing multiple synaptic proteins, may have improved suppression even further. It has been debated whether a single or few peptides from a given protein will suffice in the clinic to reinstate tolerance (44). One argument against the use of a single peptide has been that since MG patients usually recognize multiple epitopes in $\mathrm{AChR}$, it will be difficult to reinstate tolerance in multiple CD4 T cell clones with diverse epitope recognition (3). Given that many AChR-epitopes are dominant and probably do not host B cell epitopes, it would be feasible to combine several of these epitopes in a fusion protein $(49,51)$. This would also be a mechanism to broaden the scope of peptide-binding to surface molecules encoded by the HLA-Dlocus in a genetically diverse population, although the 146-162 amino acid peptide has proven to bind to quite a large and diverse range of HLA-DQ subset of haplotypes prevalent in Caucasians as well as in Afro-Americans and Asians (52).

Some researchers have investigated the concept of a therapeutic intervention by reinstating Tregs in MG patients (9). Whereas the technology appears clinically cumbersome, costly and possibly associated with significant risk it may not be a feasible future therapeutic approach. The idea that polyclonal autologous inducible Tregs (iTregs) expanded ex vivo and adoptively transferred to the patient suffers from the inconsistency that also other immune responses will be suppressed in these patients, potentially placing these patients at risk of acquiring infectious diseases or developing cancer. An alternative strategy to expanding Tregs is to transfer autologous immature or tolerogenic DCs prior to or subsequent to inducing EAMG $(53,54)$. In this way, Tregs will expand in vivo and suppress disease. These ex vivo generated DC could be treated with TGF $\beta$, IL10, or substances that promote a tolerogenic phenotype like rapamycin or statin $(11,55,56)$. However, even though this strategy seemed promising in the experimental EAMG model its clinical application appears unrealistic. By contrast, the fusion protein would achieve the induction of Tregs in vivo and in this way circumvent ex vivo expansion and handling of Tregs.

Our mCTA1-T146 fusion protein acts through suppressing the autoaggressive Th1 and Th17 cells directed against epitopes in the AChR. As aforementioned the mechanism of action is through induction of regulatory $\mathrm{CD} 4^{+} \mathrm{T}$ cells, of which both Foxp $3^{+}$Tregs and $\operatorname{Tr} 1$ cells appeared to be induced in the present study. Although we found upregulated Foxp3-gene expression in the present study, we have previously observed clear evidence of an IL-10 dependent mechanism associated with Foxp3 $3^{-}$CD4 T cells in the CIA model (26). Recently, we have further strengthened a Tr1-mediated mechanism by showing that $\mathrm{CD} 49 \mathrm{~b}^{+} \mathrm{LAG}^{+} \mathrm{CD} 4 \mathrm{~T}$ cells were induced in the draining lymph node after i.n. immunizations with our tolerogen for treatment of the EAE mouse model (C. Hansson, Univ. of Gothenburg, Sweden, unpublished observation) (57). Moreover, the same suppressive gene signature with upregulated gene expression for IL10, IL27, TGF $\beta$, and Foxp3 was observed also in this latter model $(45,58-61)$. The upregulated Foxp3-gene expression could, however, indicate that also iTregs are induced and participate in the suppression of AChR autoreactive CD4 ${ }^{+}$ $\mathrm{T}$ cells in treated mice. Perhaps, induction of both $\operatorname{Tr} 1$ and iTregs is the more likely scenario to explain the effective suppressive function of mCTA1-T146 in the EAMG model. Contrary to the acute CIA model the EAMG model has a chronic ongoing phase of disease $(21,33)$. It is promising to note that our tolerogen was equally effective in the late chronic phase of EAMG as in the early phase of disease development. We have previously demonstrated that oral administration of the T $\alpha 146-162$ synthetic peptide in milligram doses to mice reduced the T-cell proliferative response to TAChR or T $\alpha 146-162$ peptide and peptide doses given i.n. in $100 \mu \mathrm{g}$ could achieve a similar effect (29). Hence, the mCTA1-T146 fusion protein is significantly more effective and requires much lower and fewer doses (a total dose of $50 \mu \mathrm{g}$ of mCTA1-T146) to substantially reduce ongoing EAMG than peptide alone or derivatives of AChR. Ongoing studies aim to define the minimal protocol for significant improvement of EAMG disease in the mouse model using mCTA1-T146. The present study clearly demonstrates the effectiveness of the targeted mCTA1-T146 fusion protein and helps identify a new promising strategy in tolerance-inducing treatments of autoimmune diseases in general, and of MG-disease, in particular.

\section{MATERIALS AND METHODS}

\section{Animals}

Female 6- to 8-week-old C57BL6/N mice were purchased from Charles River Laboratories Italia (Calco, Italy) and housed at the animal facility of the Institute. Most experimental groups hosted 10 animals per group and more than 100 mice were tested for reinstatement of tolerance with the CTA1R9K-AChR 146-162-DD fusion protein. The group size was determined according to the protocol by Snedecore and Cochran for significance and mean disease severity in $\mathrm{C} 57 \mathrm{Bl} / 6$ mice (62). All procedures involving animals were approved by the Institute Ethical Board and Italian Ministry of Health (1064/2015-PR) and were performed according to the Italian Principle of Laboratory Animal Care (DDL 116/92 and DLgs 26/2014), and the European Communities Council Directive 86/609/EEC and 2010/63/UE. Animals were sacrificed after deep anesthesia induced by carbon dioxide. Lowgrade anesthesia with $2 \%$ isoflurane $\left(60: 40 \mathrm{~N}_{2} \mathrm{O}: \mathrm{O}_{2}\right.$, flow rate $0.8 \mathrm{l} / \mathrm{min}$ ) was induced in animals prior to immunizations and treatments. 


\section{Preparation of Fusion Proteins}

The fusion protein CTA1R9K-DD, with or without one copy of $\mathrm{OVA}_{323-339}$ peptide (CTA1/R9K-OVA-DD) or $\mathrm{AChR}_{146-162}$ peptide (CTA1R9K-AChR 146 -DD) with the torpedo amino acid sequence LGIWTYDGTKVSISPES were prepared as previously described (63). Briefly, for expression and purification, Escherichia coli BL-21 cells transformed with the different expression plasmids were grown in $2 \times$ YT medium with $50 \mathrm{mg} / \mathrm{ml}$ Kanamycin at $37^{\circ} \mathrm{C}$ overnight. Fusion proteins were produced as inclusion bodies and solubilized using $6 \mathrm{M}$ guanidine- $\mathrm{HCl}$. After refolding in distilled water, the fusion proteins were purified by affinity chromatography on IgG Sepharose (Pharmacia) as described, and stored in $\mathrm{PBS}$ at $-80^{\circ} \mathrm{C}$. Endotoxin levels were low ( $<10 \mathrm{EU}$ endotoxin/mg protein) as measured by end point chromogenic limulus amebocyte lysate methods (LAL Endochrome ${ }^{\mathrm{TM}}$, Charles River Endosafe, Charleston, SC, USA). The preparations were tested for not having any ADPribosylating activity using the Agmatine assay as described (26).

\section{EAMG Experimental Model and Treatment Protocols}

The EAMG model was performed essentially as described in the guidelines, except for testing the purification of AChR by rigorous gel electrophoresis and assessing possible contaminating synaptic proteins (see below) (21). Briefly, experimental TAChR-EAMG $(21,64)$ was induced by s.c. immunizations in the hind limbs (multiple sites) with $20 \mu \mathrm{g}$ of purified TAChR (from Torpedo californica electric organ; Aquatic Research Consultants) emulsified 1:1 ratio in Complete Freund's Adjuvant (CFA; Difco), in a total volume of $200 \mu \mathrm{l}$. After the priming immunization, two subsequent TAChR boosts $(20 \mu \mathrm{g}$ of TAChR emulsified in incomplete Freund's adjuvant in a total volume of $200 \mu \mathrm{l} /$ mouse) were given on day 30 and 60 to induce EAMG. The clinical scores and weight loss were measured by blinded investigators, ignorant about individual treatments of the mice. Experimental groups consisted of 10 mice, unless otherwise stated in the figure legends. Spleen, inguinal, and popliteal lymph nodes were taken and blood was collected and immediately processed pending further analyses. EAMG mice were treated i.n. with $5 \mu \mathrm{g}$ of fusion protein.

\section{TAChR Preparation}

TAChR was purified from Torpedo californica electric organ according to the alkali-stripped membrane protocol $(65,66)$, with minor modifications. Briefly, the electric organ tissue was homogenized in $10 \mathrm{mM}$ sodium phosphate buffer, $1 \mathrm{mM}$ EDTA, $0.02 \% \mathrm{NaN}_{3}, 0.01 \mathrm{mM}$ PMSF, pH 7.8 for $3 \mathrm{~min}$, high speed. The extract was centrifuged for $1 \mathrm{~h}$ at $100,000 \times g$. The pellet was resuspended in ice-cold water and the $\mathrm{pH}$ adjusted to 11.0 with $\mathrm{NaOH}$; the membranes were immediately centrifuged for $30 \mathrm{~min}$ at $100,000 \times g$. TAChR was solubilized from membranes with $2 \%$ sodium deoxycholate, overnight at $4^{\circ} \mathrm{C}$, then centrifuged at $100,000 \times g$ for $1 \mathrm{~h}$. TAChR concentration was determined as $\alpha$-BTX (bungarotoxin)-binding sites/milliliter and protein concentration by the BCA Protein Assay Kit (Thermo Scientific). Sodium deoxycholate was partially removed by progressive dialysis ( $1 \%$, and then $0.05 \%)$, and $\mathrm{TAChR}$ aliquots were stored at $-80^{\circ} \mathrm{C}$. The average activity of the TAChR preparation corresponded to $0.87-1.1 \mathrm{nmol}$ of ${ }^{125}$ I-labeled- $\alpha$ BTX-binding sites/milligram of protein, which is in line with the separation of membrane molecules by sucrose-gradient centrifugation, as described by Elliott et al. (66). In the final preparation the estimated TAChR concentration was $487 \mu \mathrm{g} / \mathrm{ml}$ and the total protein content was $2,000 \mu \mathrm{g} / \mathrm{ml}$. Of note, the biological activity of TAChR was evaluated as the number of $\alpha$-BTX-binding sites/ milligram of protein, as reported in the published guidelines for the mouse EAMG model (21). This is an assay reflecting the integrity of the native $\mathrm{AChR}$ conformation, with organized $\alpha, \beta, \delta$, and $\gamma$ subunits, functionally binding to $\alpha$-BTX. A gel electrophoresis also identified the four subunits. However, a more rigorous gel electrophoresis of the preparation was not undertaken; hence, we cannot exclude that also other potential contaminating synaptic proteins were present. We applied all precautions and safety measures recommended by the manufacturer when working with BTX.

\section{EAMG Clinical Evaluation}

Each animal was weighed and scored at the beginning of each experiment and at least twice weekly until the end of the experiment; clinical scores were taken every $24 \mathrm{~h}$ or more often if the animals demonstrated severe disease (21). EAMG clinical score was assessed after exercise for $30 \mathrm{~s}$, using the grip strength test. Disease severity was graded as follows: grade 0 , normal strength and no abnormalities; grade 1, mildly decreased activity and weak grip or cry; grade 2, clinical signs present before exercise (tremor, head down, hunched posture, weak grip); grade 3, severe clinical signs at rest, no grip, moribund; grade 4, sacrifice, humane end point. EAMG was confirmed by i.p. injections of Prostigmine. Animals were sacrificed 10-12 weeks after TAChR/ CFA immunizations.

\section{Cell Proliferation}

Recall antigen responses were assessed in single cell suspensions from draining (popliteal and inguinal) lymph nodes from EAMG mice after i.n. treatment with fusion protein or PBS. Cells were cultured in quadruplicates in 96-well plates at $2 \times 10^{5}$ cells/well with $0.25 \mu \mathrm{g} / \mathrm{ml}$ TAChR or with $10 \mu \mathrm{g} / \mathrm{ml}$ T146-162 peptide (LGIWTYDGTKVSISPES); concanavalin A (ConA, $2 \mu \mathrm{g} / \mathrm{ml}$, Sigma) was used as positive control. The RPMI culture medium (Euroclone) was supplemented with 10\% FCS, 1\% Na-pyruvate, $1 \%$ non-essential aa, $1 \% \mathrm{~L}$-glutamine, $1 \%$ penicillin-streptomycin (Euroclone), $50 \mu \mathrm{M}$ 2-mercaptoethanol (Sigma), plus 1\% normal rat serum. After $72 \mathrm{~h}$ of incubation at $37^{\circ} \mathrm{C}$ and $5 \% \mathrm{CO}_{2}$, the cultures were pulsed with $0.5 \mu \mathrm{Ci}\left[{ }^{3} \mathrm{H}\right]$-thymidine/well for $18 \mathrm{~h}$, and cell proliferation was measured using a beta counter (PerkinElmer).

\section{Muscle AChR Content}

Mouse AChR was extracted from the whole mouse carcass. Each carcass was weighed and homogenized for $1 \mathrm{~min}$ at high speed in four volumes of homogenization buffer $(0.1 \mathrm{M} \mathrm{NaCl}, 10 \mathrm{mM}$ $\mathrm{NaN}_{3}, 0.01 \mathrm{M}$ EDTA, 0.01 M EGTA, 0.01 M iodoacetamide, 
$1 \mathrm{mM}$ PMSF, $1 \mathrm{mM}$ sodium phosphate buffer, $\mathrm{pH} 7.5)$. The homogenized extract was centrifuged $30 \mathrm{~min}$ at $17,000 \times g$ and pellet was homogenized for $1 \mathrm{~min}$ at high speed in one volume of homogenization buffer. AChR was solubilized from membranes with Triton X-100 (10\%) in Tris buffer, for $4 \mathrm{~h}$ at $4^{\circ} \mathrm{C}$, then centrifuged at $100,000 \times g$ for $30 \mathrm{~min}\left(4^{\circ} \mathrm{C}\right)$. Duplicate $0.1 \mathrm{ml}$ aliquots of mouse muscle AChR crude extract were incubated with an excess of $\left[{ }^{125} \mathrm{I}\right] \alpha-\mathrm{BTX}$, and transferred to a DE-81 DEAE disk followed by washing with Triton X-100 (0.5\%) Tris buffer. Radioactivity was determined by gamma counting. Unspecific binding (from parallel tubes pre-incubated with unlabeled $\alpha$-BTX) was subtracted from each sample. Results were expressed as picomoles of toxinbinding sites per gram of carcass.

\section{Anti-AChR Antibody Titer}

Acetylcholine receptor-specific antibodies were determined in serum from individual mice by a radioimmunoprecipitation assay (67). Mouse AChR was extracted from whole carcass, as previously described, and labeled with $2 \mathrm{nM}\left[{ }^{125} \mathrm{I}\right] \alpha$-BTX. Serum samples were incubated overnight with $\left[{ }^{125} \mathrm{I}\right]-\alpha \mathrm{BTX}$ labeled mouse AChR (0.5 pM). Antibody-AChR complexes were precipitated by adding an excess of rabbit anti-mouse IgG (DAKO). Pellets were washed twice with cold PBS plus $0.5 \%$ Triton X-100 (Carlo Erba) and [ $\left.{ }^{125} \mathrm{I}\right]-\alpha \mathrm{BTX}$ labeling was assessed using a $\gamma$-counter (PerkinElmer). Serum samples incubated with mouse AChR and pre-incubated in excess of unlabeled $\alpha$-BTX (Life Technologies) (unspecific binding) were subtracted from test samples. The anti-AChR antibody titers were expressed as $\mathrm{pM}$ of $\left[{ }^{125} \mathrm{I}\right] \alpha$-BTX-binding sites precipitated per milliliter of serum.

\section{cDNA Synthesis and qPCR}

Total RNA was extracted from the draining lymph nodes using the Trizol reagent; cDNA was synthesized from RNA using random hexamers and reverse transcriptase (all from Life Technologies). Real-time quantitative PCR for IFN $\gamma$, IL17, TGF $\beta$, IL10, IL27, FoxP3 was performed using Assay-on Demand Gene Expression Products (Life Technologies). GAPDH was used as housekeeping endogenous genes. mRNA levels of target genes were expressed as relative values $\left(2^{-\Delta c t} \times 100\right)$ normalized toward the chosen housekeeping genes, in which $\Delta \mathrm{Ct}$ represents the difference between cycle threshold $(\mathrm{Ct})$ of the target gene and $\mathrm{Ct}$ of the housekeeping gene. Real-time PCR reactions were performed in duplicates using an ABI Prism 7500 FAST RealTime PCR System (Life Technologies).

\section{Multiple Cytokine Assay}

Culture supernatants were analyzed for IFN $\gamma$, IL17, and IL10 cytokine expression by ProcartaPlex Mouse IFN $\gamma$, IL17A, and IL10 Simplex kits (Affymetrix-eBioscience), according to the

\section{REFERENCES}

1. Gilhus NE. Myasthenia gravis. NEngl J Med (2016) 375:2570-81. doi:10.1056/ NEJMra1602678

2. Meriggioli MN, Sanders DB. Autoimmune myasthenia gravis: emerging clinical and biological heterogeneity. Lancet Neurol (2009) 8:475-90. doi:10.1016/ S1474-4422(09)70063-8 manufacturer's instructions. The limit for detection of individual cytokines was $2-5 \mathrm{pg} / \mathrm{ml}$. Plates were read in a Luminex MAGPIX instrument (Luminex Corporation). Analysis of data and quantification of cytokines was performed using the Luminex xPONENT Software (Luminex Corporation) on the basis of corresponding standards curves.

\section{Statistical Analysis}

Results were statistically analyzed using GraphPad Prism v5.0 (GraphPad Prism, CA, USA) and values were given as means \pm SEM or SD, as indicated. Statistical analysis was performed according to the nature of data. Normally distributed data were analyzed using one- or two-way ANOVA followed by appropriate post hoc comparisons. Non-parametrically distributed data were analyzed using the Mann-Whitney test. Statistical significance is given as $p$-values: ${ }^{*} p<0.05,{ }^{* *} p<0.01$, and ${ }^{\star * *} p<0.001$.

\section{ETHICS STATEMENT}

This study was carried out in accordance with the recommendations of the Institute Ethical Board and Italian Ministry of Health (1064/2015-PR) and were performed in respect to the Italian Principle of Laboratory Animal Care (DDL 116/92 and DLgs 26/2014), and in accordance to European Communities Council Directive 86/609/EEC and 2010/63/UE.

\section{AUTHOR CONTRIBUTIONS}

AC and ER performed the animal experiments. AC, SS, KS, and $\mathrm{CL}-\mathrm{F}$ analyzed the data and interpreted the results. AC and CL-F prepared the figures. NL and FB designed the experiments. AC, $\mathrm{NL}$, and FB wrote the manuscript.

\section{ACKNOWLEDGMENTS}

The authors thank the Centre for Cellular Imaging and the Laboratory for Experimental Biomedicine facility at the University of Gothenburg.

\section{FUNDING}

These studies were partly financed by funds from the Swedish Research Council, the Swedish Cancer Foundation, The Swedish Foundation for Strategic Research, Knut and Alice Wallenberg's Foundation, LUA/ALF funding, EU FP7 ITN UniVacFlu and INNOVATION-1, UNISEC project, Eurostars project E19480 TolerizeMG, and the Italian Ministry of Health (WFR PE-2011-02346818).
3. Luo J, Lindstrom J. AChR-specific immunosuppressive therapy of myasthenia gravis. Biochem Pharmacol (2015) 97:609-19. doi:10.1016/j.bcp.2015.07.011

4. Oshima M, Deitiker PR, Glenn Smith R, Mosier D, Zouhair Atassi M. T-cell recognition of acetylcholine receptor provides a reliable means for monitoring autoimmunity to acetylcholine receptor in antibody-negative myasthenia gravis patients. Autoimmunity (2012) 45:153-60. doi:10.3109/08916934.2011. 611550 
5. Alahgholi-Hajibehzad M, Kasapoglu P, Jafari R, Rezaei N. The role of T regulatory cells in immunopathogenesis of myasthenia gravis: implications for therapeutics. Expert Rev Clin Immunol (2015) 11:859-70. doi:10.1586/ 1744666X.2015.1047345

6. Gradolatto A, Nazzal D, Truffault F, Bismuth J, Fadel E, Foti M, et al. Both Treg cells and Tconv cells are defective in the myasthenia gravis thymus: roles of IL-17 and TNF- $\alpha$. J Autoimmun (2014) 52:53-63. doi:10.1016/j. jaut.2013.12.015

7. Kohler S, Keil TOP, Hoffmann S, Swierzy M, Ismail M, Rückert JC, et al. $\mathrm{CD} 4+$ FoxP3 + T regulatory cell subsets in myasthenia gravis patients. Clin Immunol (2017) 179:40-6. doi:10.1016/j.clim.2017.03.003

8. Thiruppathi M, Rowin J, Ganesh B, Sheng JR, Prabhakar BS, Meriggioli MN. Impaired regulatory function in circulating CD4+CD25highCD127low/T cells in patients with myasthenia gravis. Clin Immunol (2012) 145:209-23. doi:10.1016/j.clim.2012.09.012

9. Aricha R, Reuveni D, Fuchs S, Souroujon MC. Suppression of experimental autoimmune myasthenia gravis by autologous $\mathrm{T}$ regulatory cells. J Autoimmun (2016) 67:57-64. doi:10.1016/j.jaut.2015.09.005

10. Gertel-Lapter S, Mizrachi K, Berrih-Aknin S, Fuchs S, Souroujon MC. Impairment of regulatory $\mathrm{T}$ cells in myasthenia gravis: studies in an experimental model. Autoimmun Rev (2013) 12:894-903. doi:10.1016/j. autrev.2013.03.009

11. Li X-L, Liu Y, Cao L-L, Li H, Yue L-T, Wang S, et al. Atorvastatin-modified dendritic cells in vitro ameliorate experimental autoimmune myasthenia gravis by up-regulated Treg cells and shifted Th1/Th17 to Th2 cytokines. Mol Cell Neurosci (2013) 56:85-95. doi:10.1016/j.mcn.2013.03.005

12. Meng Q-F, Zhang Z, Wang Y-J, Chen W, Li F-F, Yue L-T, et al. Astilbin ameliorates experimental autoimmune myasthenia gravis by decreased Th17 cytokines and up-regulated T regulatory cells. J Neuroimmunol (2016) 298:138-45. doi:10.1016/j.jneuroim.2016.07.016

13. Schaffert H, Pelz A, Saxena A, Losen M, Meisel A, Thiel A, et al. IL-17producing $\mathrm{CD} 4+\mathrm{T}$ cells contribute to the loss of $\mathrm{B}$-cell tolerance in experimental autoimmune myasthenia gravis. Eur J Immunol (2015) 45:1339-47. doi:10.1002/eji.201445064

14. Liu R, Hao J, Dayao CS, Shi F-D, Campagnolo DI. T-bet deficiency decreases susceptibility to experimental myasthenia gravis. Exp Neurol (2009) 220: 366-73. doi:10.1016/j.expneurol.2009.09.022

15. Melzer N, Ruck T, Fuhr P, Gold R, Hohlfeld R, Marx A, et al. Clinical features, pathogenesis, and treatment of myasthenia gravis: a supplement to the guidelines of the German Neurological Society. J Neurol (2016) 263:1473-94. doi:10.1007/s00415-016-8045-z

16. Steinman L, Merrill JT, McInnes IB, Peakman M. Optimization of current and future therapy for autoimmune diseases. Nat Med (2012) 18:59-65. doi:10.1038/nm.2625

17. Maggi L, Baggi F, Mantegazza R. Orphan drugs to treat myasthenia gravis. Expert Opin Orphan Drugs (2013) 1:373-84. doi:10.1517/21678707.2013. 779920

18. Garber K. Immunology: a tolerant approach. Nature (2014) 507:418-20. doi:10.1038/507418a

19. Shi FD, Bai XF, Li HL, Huang Y-M, Van der Meide PH, Link H. Nasal tolerance in experimental autoimmune myasthenia gravis (EAMG): induction of protective tolerance in primed animals. Clin Exp Immunol (1998) 111:506-12. doi:10.1046/j.1365-2249.1998.00521.x

20. Lazaridis K, Baltatzidi V, Trakas N, Koutroumpi E, Karandreas N, Tzartos SJ. Characterization of a reproducible rat EAMG model induced with various human acetylcholine receptor domains. J Neuroimmunol (2017) 303:13-21. doi:10.1016/j.jneuroim.2016.12.011

21. Tuzun E, Berrih-Aknin S, Brenner T, Kusner LL, Le Panse R, Yang H, et al. Guidelines for standard preclinical experiments in the mouse model of myasthenia gravis induced by acetylcholine receptor immunization. Exp Neurol (2014) 270:11-7. doi:10.1016/j.expneurol.2015.02.009

22. Arellano B, Graber DJ, Sentman CL. Regulatory T cell-based therapies for autoimmunity. Discov Med (2016) 22:73-80.

23. Freedman MS. Improving long-term follow-up studies of immunomodulatory therapies. Neurology (2011) 76:S35-8. doi:10.1212/WNL.0b013e3182050599

24. Lutterotti A, Yousef S, Sputtek A, Sturner KH, Stellmann J-P, Breiden P, et al. Antigen-specific tolerance by autologous myelin peptide-coupled cells: a phase 1 trial in multiple sclerosis. Sci Transl Med (2013) 5:ra75-188. doi:10.1126/scitranslmed.3006168
25. Maldonado RA, LaMothe RA, Ferrari JD, Zhang A-H, Rossi RJ, Kolte PN, et al. Polymeric synthetic nanoparticles for the induction of antigen-specific immunological tolerance. Proc Natl Acad Sci U S A (2015) 112:E156-65. doi:10.1073/pnas.1408686111

26. Hasselberg A, Schön K, Tarkowski A, Lycke N. Role of CTA1R7K-COL-DD as a novel therapeutic mucosal tolerance-inducing vector for treatment of collagen-induced arthritis. Arthritis Rheum (2009) 60:1672-82. doi:10.1002/ art.24566

27. Hansson C, Schön K, Kalbina I, Strid Å, Andersson S, Bokarewa MI, et al. Feeding transgenic plants that express a tolerogenic fusion protein effectively protects against arthritis. Plant Biotechnol J (2016) 14:1106-15. doi:10.1111/ pbi. 12479

28. White AM, Wraith DC. Tr1-like T cells - an enigmatic regulatory T cell lineage. Front Immunol (2016) 7:355. doi:10.3389/fimmu.2016.00355

29. Baggi F, Andreetta F, Caspani E, Milani M, Longhi R, Mantegazza R, et al. Oral administration of an immunodominant T-cell epitope downregulates Th1/Th2 cytokines and prevents experimental myasthenia gravis. J Clin Invest (1999) 104:1287-95. doi:10.1172/JCI7121

30. Infante AJ, Thompson PA, Krolick KA, Wall KA. Determinant selection in murine experimental autoimmune myasthenia gravis. Effect of the bm12 mutation on $\mathrm{T}$ cell recognition of acetylcholine receptor epitopes. J Immunol (1991) 146:2977-82.

31. Batten M, Li J, Yi S, Kljavin NM, Danilenko DM, Lucas S, et al. Interleukin 27 limits autoimmune encephalomyelitis by suppressing the development of interleukin 17-producing T cells. Nat Immunol (2006) 7:929-36. doi:10.1038/ ni1375

32. Sundstedt A, O’Neill EJ, Nicolson KS, Wraith DC. Role for IL-10 in suppression mediated by peptide-induced regulatory T cells in vivo. J Immunol (2003) 170:1240-8. doi:10.4049/jimmunol.170.3.1240

33. Mantegazza R, Cordiglieri C, Consonni A, Baggi F. Animal models of myasthenia gravis: utility and limitations. Int J Gen Med (2016) 9:53-64. doi:10.2147/IJGM.S88552

34. Roncarolo MG, Gregori S, Bacchetta R, Battaglia M. Tr1 cells and the counterregulation of immunity: natural mechanisms and therapeutic applications. Curr Top Microbiol Immunol (2014) 380:39-68. doi:10.1007/978-3-66243492-5_3

35. Stumhofer JS, Laurence A, Wilson EH, Huang E, Tato CM, Johnson LM, et al. Interleukin 27 negatively regulates the development of interleukin 17-producing $\mathrm{T}$ helper cells during chronic inflammation of the central nervous system. Nat Immunol (2006) 7:937-45. doi:10.1038/ni1376

36. Okumura S, McIntosh K, Drachman DB. Oral administration of acetylcholine receptor: effects on experimental myasthenia gravis. Ann Neurol (1994) 36:704-13. doi:10.1002/ana.410360504

37. Ma CG, Zhang GX, Xiao BG, Link J, Olsson T, Link H. Suppression of experimental autoimmune myasthenia gravis by nasal administration of acetylcholine receptor. J Neuroimmunol (1995) 58:51-60. doi:10.1016/0165-5728(94)00187-S

38. Barchan D, Souroujon M, Im S-H, Antozzi C, Fuchs S. Antigen-specific modulation of experimental myasthenia gravis: nasal tolerization with recombinant fragments of the human acetylcholine receptor alpha-subunit. Proc Natl Acad Sci U S A (1999) 96:8086-91. doi:10.1073/pnas.96.14. 8086

39. Im SH, Barchan D, Fuchs S, Souroujon MC. Mechanism of nasal tolerance induced by a recombinant fragment of acetylcholine receptor for treatment of experimental myasthenia gravis. J Neuroimmunol (2000) 111:161-8. doi:10.1016/S0165-5728(00)00395-7

40. Atassi MZ, Ruan KH, Jinnai K, Oshima M, Ashizawa T. Epitope-specific suppression of antibody response in experimental autoimmune myasthenia gravis by a monomethoxypolyethylene glycol conjugate of a myasthenogenic synthetic peptide. Proc Natl Acad Sci U S A (1992) 89:5852-6. doi:10.1073/ pnas.89.13.5852

41. Karachunski PI, Ostlie NS, Okita DK, Conti-Fine BM. Prevention of experimental myasthenia gravis by nasal administration of synthetic acetylcholine receptor T epitope sequences. J Clin Invest (1997) 100:3027-35. doi:10.1172/ JCI119857

42. Pearson RM, Casey LM, Hughes KR, Miller SD, Shea LD. In vivo reprogramming of immune cells: technologies for induction of antigenspecific tolerance. Adv Drug Deliv Rev (2017) 114:240-55. doi:10.1016/j. addr.2017.04.005 
43. Santambrogio L, Sato AK, Carven GJ, Belyanskaya SL, Strominger JL, Stern LJ. Extracellular antigen processing and presentation by immature dendritic cells. Proc Natl Acad Sci U S A (1999) 96:15056-61. doi:10.1073/ pnas.96.26.15056

44. Streeter HB, Rigden R, Martin KF, Scolding NJ, Wraith DC. Preclinical development and first-in-human study of ATX-MS-1467 for immunotherapy of MS. Neurol Neuroimmunol Neuroinflamm (2015) 2:e93. doi:10.1212/ NXI.0000000000000093

45. Burton BR, Britton GJ, Fang H, Verhagen J, Smithers B, Sabatos-Peyton CA, et al. Sequential transcriptional changes dictate safe and effective antigenspecific immunotherapy. Nat Commun (2014) 5:4741. doi:10.1038/ ncomms5741

46. Semmrich $M$, Plantinga $M$, Svensson-Frej $M$, Uronen-Hansson $H$, Gustafsson T, Mowat AM, et al. Directed antigen targeting in vivo identifies a role for $\mathrm{CD} 103+$ dendritic cells in both tolerogenic and immunogenic T-cell responses. Mucosal Immunol (2012) 5:150-60. doi:10.1038/mi.2011.61

47. Takenaka MC, Quintana FJ. Tolerogenic dendritic cells. Semin Immunopathol (2017) 39:113-20. doi:10.1007/s00281-016-0587-8

48. Lindstrom J, Peng X, Kuryatov A, Lee E, Anand R, Gerzanich V, et al. Molecular and antigenic structure of nicotinic acetylcholine receptors. Ann N Y Acad Sci (1998) 841:71-86. doi:10.1111/J.1749-6632.1998.TB10910.X

49. Dalakas MC. Novel future therapeutic options in myasthenia gravis. Autoimmun Rev (2013) 12:936-41. doi:10.1016/j.autrev.2013.03.006

50. Luo J, Taylor P, Losen M, de Baets MH, Shelton GD, Lindstrom J. Main immunogenic region structure promotes binding of conformation-dependent myasthenia gravis autoantibodies, nicotinic acetylcholine receptor conformation maturation, and agonist sensitivity. J Neurosci (2009) 29:13898-908. doi:10.1523/JNEUROSCI.2833-09.2009

51. Yi H-J, Chae C-S, So J-S, Tzartos SJ, Souroujon MC, Fuchs S, et al. Suppression of experimental myasthenia gravis by a B-cell epitope-free recombinant acetylcholine receptor. Mol Immunol (2008) 46:192-201. doi:10.1016/j. molimm.2008.08.264

52. Deitiker PR, Oshima M, Smith RG, Mosier DR, Atassi MZ. Subtle differences in HLA DQ haplotype-associated presentation of AChR $\alpha$-chain peptides may suffice to mediate myasthenia gravis. Autoimmunity (2006) 39:277-88. doi:10.1080/08916930600738581

53. Roncarolo MG, Levings MK, Traversari C. Differentiation of T regulatory cells by immature dendritic cells. J Exp Med (2001) 193:F5-9. doi:10.1084/ jem.193.2.F5

54. Xiao B-G, Duan R-S, Link H, Huang Y-M. Induction of peripheral tolerance to experimental autoimmune myasthenia gravis by acetylcholine receptor-pulsed dendritic cells. Cell Immunol (2003) 223:63-9. doi:10.1016/ S0008-8749(03)00118-7

55. Duan R-S, Bandara Adikari S, Huang Y-M, Link H, Xiao B-G. Protective potential of experimental autoimmune myasthenia gravis in Lewis rats by IL-10-modified dendritic cells. Neurobiol Dis (2004) 16:461-7. doi:10.1016/j. nbd.2004.03.017

56. Yarilin D, Duan R, Huang Y-M, Xiao B-G. Dendritic cells exposed in vitro to TGF- $\beta 1$ ameliorate experimental autoimmune myasthenia gravis. Clin Exp Immunol (2002) 127:214-9. doi:10.1046/j.1365-2249.2002.01748.x

57. Gagliani N, Magnani CF, Huber S, Gianolini ME, Pala M, LiconaLimon P, et al. Coexpression of CD49b and LAG-3 identifies human and mouse T regulatory type 1 cells. Nat Med (2013) 19:739-46. doi:10.1038/ nm.3179

58. Okamura T, Fujio K, Shibuya M, Sumitomo S, Shoda H, Sakaguchi S, et al. CD4+CD25-LAG3+ regulatory $\mathrm{T}$ cells controlled by the transcription factor Egr-2. Proc Natl Acad Sci U S A (2009) 106:13974-9. doi:10.1073/ pnas.0906872106

59. Kochetkova I, Thornburg T, Callis G, Pascual DW. Segregated regulatory CD39+CD4+ T cell function: TGF- $\beta$-producing Foxp3- and IL- 10 -producing Foxp3+ cells are interdependent for protection against collagen-induced arthritis. J Immunol (2011) 187:4654-66. doi:10.4049/jimmunol.1100530

60. Fletcher JM, Lonergan R, Costelloe L, Kinsella K, Moran B, O’Farrelly C, et al. CD39+Foxp3+ regulatory $\mathrm{T}$ cells suppress pathogenic Th17 cells and are impaired in multiple sclerosis. J Immunol (2009) 183:7602-10. doi:10.4049/ jimmunol.0901881

61. Awasthi A, Carrier Y, Peron JPS, Bettelli E, Kamanaka M, Flavell RA, et al. A dominant function for interleukin 27 in generating interleukin 10-producing anti-inflammatory T cells. Nat Immunol (2007) 8:1380-9. doi:10.1038/ ni1541

62. Snedecor GW, Cochran WG. Statistical Methods. 8th ed. Ames: Iowa State Press (1989).

63. Agren LC, Ekman L, Löwenadler B, Lycke NY. Genetically engineered nontoxic vaccine adjuvant that combines B cell targeting with immunomodulation by cholera toxin A1 subunit. J Immunol (1997) 158:3936-46. doi:10.1016/ S0165-2478(97)88001-7

64. Baggi F, Annoni A, Ubiali F, Milani M, Longhi R, Scaioli W, et al. Breakdown of tolerance to a self-peptide of acetylcholine receptor alpha-subunit induces experimental myasthenia gravis in rats. J Immunol (2004) 172:2697-703. doi:10.4049/jimmunol.172.4.2697

65. Bellone M, Ostlie N, Karachunski P, Manfredi AA, Conti-Tronconi BM. Cryptic epitopes on the nicotinic acetylcholine receptor are recognized by autoreactive CD4+ cells. J Immunol (1993) 151:1025-38.

66. Elliott J, Blanchard SG, Wu W, Miller J, Strader CD, Hartig P, et al. Purification of Torpedo californica post-synaptic membranes and fractionation of their constituent proteins. Biochem J (1980) 185:667-77. doi:10.1042/bj1850667

67. Lindstrom J, Einarson B, Tzartos S. Production and assay of antibodies to acetylcholine receptors. Methods Enzymol (1981) 74:432-60. doi:10.1016/0076-6879(81)74031-X

Conflict of Interest Statement: NL has intellectual property related to MG treatment. NL is affiliated with the Toleranzia AB company that develops MG-specific treatments based on the fusion protein described in the present study. Disclosures are managed in compliance with the policies of University of Gothenburg, Sweden. AC, SS, KS, CL-F, ER, and FB have nothing to disclose.

Copyright (C) 2017 Consonni, Sharma, Schön, Lebrero-Fernández, Rinaldi, Lycke and Baggi. This is an open-access article distributed under the terms of the Creative Commons Attribution License (CC BY). The use, distribution or reproduction in other forums is permitted, provided the original author(s) or licensor are credited and that the original publication in this journal is cited, in accordance with accepted academic practice. No use, distribution or reproduction is permitted which does not comply with these terms. 